\title{
Purification and analytical characterization of an anti- CD4 monoclonal antibody for human therapy
}

\author{
A.H. Guse*, A.D. Milton ${ }^{\text {h }}$, H. Schulze-Koops, B. Müller, E. Roth and B. Simmer \\ Max-Planck-Gesellschaft, Klinische Arbeitsgruppe für Rheumatologie/Immunologie am Institut für Klinische Immunologie der \\ Universität Erlangen-Nürnberg, Schwabachanlage 10, W-8520 Erlangen (Germany)
}

\section{H. Wächter}

Landesuntersuchungsamt für das Gesundheitswesen Nordbayern, Henkestrasse 9-11, W-8520 Erlangen (Germany)

\section{E. Weiss}

Institut für Anthropologie und Humangenetik, Richard-Wagnerstrasse 10/I, W-8000 Munich 2 (Germany)

\section{F. Emmrich}

Max-Planck-Gesellschaft, Klinische Arbeitsgruppe für Rheumatologie/Immunologie am Institut für Klinische Immunologie der Universität Erlangen-Nürnberg, Schwabachanlage 10, W-8520 Erlangen (Germany)

\section{ABSTRACT}

A purification process for the monclonal anti-CD4 antibody $\mathrm{MAX} .16 \mathrm{H} 5$ was developed on an analytical scale using $\left(\mathrm{NH}_{4}\right)_{2} \mathrm{SO}_{4}$ precipitation, anion-exchange chromatography on MonoQ or Q-Sepharose, hydrophobic interaction chromatography on phenylSepharose and gel filtration chromatography on Superdex 200. The purification schedule was scaled up and gram amounts of MAX.16H5 were produced on corresponding BioPilot columns. Studies of the identity, purity and possible contamination by a broad range of methods showed that the product was highly purified and free from contaminants such as mouse DNA, viruses, pyrogens and irritants. Overall, the analytical data confirm that the monoclonal antibody MAX.16H5 prepared by this protocol is suitable for human therapy.

\section{INTRODUCTION}

Several methods for the purification of monoclonal antibodies (mAb) have been published (reviewed in ref. 1). The correct choice of the purification method mainly depends on the use for which the $\mathrm{mAb}$ is intended. Also, other

\footnotetext{
* Corresponding author. Present address: Universität Hamburg, Institut für Physiologische Chemie, Martinstrasse 52, D-20251 Hamburg, Germany.

Present address: L.A.B. GmbH, Wegenerstrasse 13, W7910 Neu-Ulm, Germany.
}

parameters including source material, class and subclass of mAb may be important, as these may influence $\mathrm{mAb}$ behaviour in certain column chromatographic techniques. MAbs to be used for human therapy must be purified and the final product has to be analysed in accordance with the "guidelines on the production and quality control of monoclonal antibodies of murine origin intended for use in man" [2].

In this paper we describe the development of a purification schedule for the mouse anti-CD4 mAb MAX.16H5, which has been and is still used successfully in single-case treatments of 
several autoimmune diseases (reviewed in ref. 3). $\mathrm{CD} 4(\mathrm{CD}=$ cluster of differentiation) is a cell surface marker found on (i) the $\mathrm{T}$ lymphocyte helper subset, (ii) monocytes/macrophages and (iii) eosinophiles. MAX.16H5 recognizes a unique epitope in the first extracellular domain of the human CD4 molecule [4]. This epitope resides in the binding site of human immunodeficiency virus glycoprotein 120 , as demonstrated by insertion mutants containing human CD4 sequences in a rat $\mathrm{CD} 4$ background [5].

The optimized purification protocol was scaled up to the preparative scale and gram amounts of mAb MAX.16H5 were produced. Analytical procedures for studying identity, purity and possible contamination showed that the final product fulfilled the criteria for use in man.

\section{EXPERIMENTAL}

\section{Analytical-scale purification of $m A b$ \\ MAX.16H5}

The purification protocol for mAb MAX.16H5 was set up using either milligram amounts of purified MAX.16H5 or ascites fluid containing milligram amounts of MAX.16H5 as samples. The computerized MT2 HPLC system (Kontron Instruments, Neufahrn, Germany) equipped with various fast protein (FPLC) columns (Pharmacia, Freiburg, Germany) as presented in the Results and Discussion section was used.

\section{DNA-spiking experiments}

Mixtures of mAb MAX.16H5 (0.5-1 mg) and $1 \mathrm{mg}$ of calf thymus DNA (Boehringer, Mannheim, Germany) were chromatographed on an analytical scale on HiLoad Superdex 200 16/60 Prep grade columns (Pharmacia) using identical buffer systems as indicated for the preparative runs (see below). The elution protocols were adapted to the column sizes. The DNA content was measured in the MAX.16H5 fraction by fluorimetry using bisbenzimide H33258 [6].

\section{Preparative-scale purification of $m A b$ MAX.16H5}

$\left(\mathrm{NH}_{4}\right)_{2} \mathrm{SO}_{4}$ precipitation. Ascites fluid containing mAb MAX.16H5 was precipitated with equal amounts of saturated $\left(\mathrm{NH}_{4}\right)_{2} \mathrm{SO}_{4}$ solution by dropwise addition at room temperature. To complete precipitation the solution was stirred for $2 \mathrm{~h}$ at room temperature and $1 \mathrm{~h}$ at $4^{\circ} \mathrm{C}$. The precipitate was spun $\left(4500 \mathrm{~g}, 30 \mathrm{~min}, 20^{\circ} \mathrm{C}\right)$ and the pellet was dissolved in the original volume of $50 \%$ saturated $\left(\mathrm{NH}_{4}\right)_{2} \mathrm{SO}_{4}$ solution. After a second centrifugation $\left(11300 \mathrm{~g}, 20 \mathrm{~min}, 20^{\circ} \mathrm{C}\right)$, the pellet was dissolved in half of the original volume of $50 \%$ saturated $\left(\mathrm{NH}_{4}\right)_{2} \mathrm{SO}_{4}$ solution. After a third centrifugation $(11300 \mathrm{~g}, 30 \mathrm{~min}$, $20^{\circ} \mathrm{C}$ ), the pellet was dissolved in 0.3 times the original volume in $20 \mathrm{~m} M$ Tris- $\mathrm{HCl}-40 \mathrm{mM}$ $\mathrm{NaCl}$ ( $\mathrm{pH} \mathrm{7.5).} \mathrm{This} \mathrm{solution} \mathrm{was} \mathrm{again} \mathrm{cen-}$ trifuged $\left(11300 \mathrm{~g}, 15 \mathrm{~min}, 20^{\circ} \mathrm{C}\right)$ and the supernatant was used for subsequent steps.

Delipidation by $n$-hexane. To remove lipids, equal volumes of $\left(\mathrm{NH}_{4}\right)_{2} \mathrm{SO}_{4}$-precipitated material and $n$-hexane were vortex mixed. The phases were separated by centrifugation ( $338 \mathrm{~g}, 6$ min, $4^{\circ} \mathrm{C}$ ). The extraction was repeated twice. The final aqueous extract was centrifuged at $200000 \mathrm{~g}\left(30 \mathrm{~min}, 4^{\circ} \mathrm{C}\right)$ to remove traces of remaining $n$-hexane.

Anion-exchange chromatography. A BioPilot system (Pharmacia) was used for all preparative column chromatographic steps. Detection was effected with a UV monitor set to $280 \mathrm{~nm}$ and with a conductivity monitor. Fractions of $10 \mathrm{ml}$ were collected by a FRAC- 100 fraction collector (Pharmacia) and were pooled manually. Pooled fractions corresponding to one peak were analysed for protein and IgG content (sec below) and then further purified. After equilibration of the O-Sepharose HP 35/100 column (Pharmacia) with low-salt buffer A [40 $\mathrm{m} M$ NaCl-20 $\mathrm{m} M$ Tris- $\mathrm{HCl}(\mathrm{pH} \mathrm{7.5)],} \mathrm{the} \mathrm{sample} \mathrm{was} \mathrm{loaded} \mathrm{at}$ $3.0 \mathrm{ml} / \mathrm{min}$. The gradient for elution of columnbound material was as follows at a flow-rate of $3.6 \mathrm{ml} / \mathrm{min}$ [expressed as \% of buffer $\mathrm{B}$ containing $1 M$ NaCl-20 mM Tris- $\mathrm{HCl}(\mathrm{pH} \mathrm{7.5)]:}$ isocratic at $0 \% \mathrm{~B}$ for $36 \mathrm{ml}$; linear up to $15 \% \mathrm{~B}$ in $108 \mathrm{ml}$; isocratic at $15 \% \mathrm{~B}$ for $126 \mathrm{ml}$; linear up to $100 \% \mathrm{~B}$ in $72 \mathrm{ml}$; and isocratic at $100 \% \mathrm{~B}$ for $72 \mathrm{ml}$. Fractions were collected under sterile conditions in a laminar flow bench.

Hydrophobic interaction chromatography. Dry $\left(\mathrm{NH}_{4}\right)_{2} \mathrm{SO}_{4}$ was added to mAb MAX.16H5 solution eluted from $\mathrm{Q}$-Sepharose to a final concentration of $0.5 \mathrm{M}$. The column (phenyl- 
Sepharose HP 35/100; Pharmacia) was equilibrated with buffer $\mathrm{A}\left[0.5 \mathrm{M}\left(\mathrm{NH}_{4}\right)_{2} \mathrm{SO}_{4}-70 \mathrm{mM}\right.$ $\mathrm{KH}_{2} \mathrm{PO}_{4}-\mathrm{K}_{2} \mathrm{HPO}_{4}$ adjusted to $\mathrm{pH}$ 7.2]. Loading of samples was done at flow-rates between 3 and $10 \mathrm{ml} / \mathrm{min}$. The gradient for elution of columnbound material was as follows at a flow-rate of $10 \mathrm{ml} / \mathrm{min}$ [expressed as \% of buffer $\mathrm{B}$ containing $70 \mathrm{mM} \mathrm{KH}_{2} \mathrm{PO}_{4}-\mathrm{K}_{2} \mathrm{HPO}_{4}$ (pH 7.2)]: isocratic at $0 \% \mathrm{~B}$ for $300 \mathrm{ml}$; linear up to $100 \%$ $\mathrm{B}$ in $700 \mathrm{ml}$; and isocratic at $100 \% \mathrm{~B}$ for $350 \mathrm{ml}$. Fractions were collected under sterile conditions in a laminar flow bench.

Ultrafiltration. The ultrafiltration apparatus (Amicon, Danvers, MA, USA) was made pyrogen-free by washing with $1 M \mathrm{NaOH}$ for 2-3 h and was subsequently autoclaved. Concentration of mAb MAX.16H5 solution from hydrophobic interaction chromatography was done using MSO or XM50 membranes (Amicon). The solutions were concentrated in order to be used with the gel filtration columns listed below.

Gel filtration chromatography. Gel filtration was carried out on Superdex 200 Prep grade $35 / 600$ or $60 / 600$ (Pharmacia). The column was equilibrated with $75 \mathrm{~m} M \quad \mathrm{NaCl}-60 \mathrm{~m} M$ $\mathrm{Na}_{2} \mathrm{HPO}_{4}-\mathrm{NaH}_{2} \mathrm{PO}_{4}$ adjusted to $\mathrm{pH}$ 7.4. The samples (sample volume as rated in the manual from the column supplier) were chromatographed at flow-rates of $4 \mathrm{ml} / \mathrm{min}(35 / 600 \mathrm{col}-$ umn) or $11.7 \mathrm{ml} / \mathrm{min}(60 / 600$ column$)$. Fractions were collected under sterile conditions in a laminar flow bench.

\section{Cleaning-in-place (CIP) procedures}

The BioPilot system (Pharmacia) and BioPilot Q-Sepharose and phenyl-Sepharose columns were sterilized and made pyrogen-free by flushing with four column volumes of $1 M \mathrm{NaOH}$ and subsequently by washing with $0.1 \mathrm{M} \mathrm{NaOH}$ at low flow-rates $(0.5$ or $1.0 \mathrm{ml} / \mathrm{min})$ overnight. Superdex 200 columns were treated at a low flow-rate with one column volume of $1 M$ $\mathrm{NaOH}$, resulting in a treatment period of $c a .3 \mathrm{~h}$. After CIP, the columns were re-equilibrated by flushing with four column volumes of starting buffer. The pyrogen content of the columns was then checked by employing the Pyroquant 1 test (see below). Only if the column eluate was pyrogen-free were preparative runs started.
All buffers were prepared using pyrogen-free water (Ampuwa water, Fresenius, Bad Homburg, Germany) in pyrogen-free glassware and sterilized by filtration. All chemicals used were of German Pharmacopoeia (DAB) quality or analytical quality. Glassware for preparing buffers was made pyrogen-free by treatment with $1 M \mathrm{NaOH}$ for $1 \mathrm{~h}$ followed by rinsing with Ampuwa water and drying overnight in an oven at $>180^{\circ} \mathrm{C}$. Buffers were tested with the Pyroquant 1 test to confirm their pyrogen-free state before use.

\section{Protein determination}

Protein was determined using the Bio-Rad protein determination kit according to manufacturer's instructions (BioRad, Munich, Germany) and immunoglobulin $\mathrm{G}$ (IgG) as a standard.

\section{Analytical procedures on bulk final processed product (BFPP)}

IgG-specific enzyme-linked immunosorbent assay (ELISA). Appropriate dilutions of standard and samples were incubated in goat antimouse IgG-coated Immuno Plate Maxi Sorp (Nunc, Roskilde, Denmark) 96-well plates for 1 h at $37^{\circ} \mathrm{C}$. After washing, goat anti-mouse IgGand IgM-alkaline phosphatase conjugates (Dianova, Hamburg, Germany) were added. After washing, the substrate $p$-nitrophenyl phosphate (Sigma, Deisenhofen, Germany) was added. The plates were measured in a Type 400 A ELISA-Reader (SLT-Labinstruments, Vienna, Austria) after 1 or $2 \mathrm{~h}$ at $450 \mathrm{~nm}$.

Pro Ana Mabs assay. Concentration assays were performed with a Pro Ana Mabs system (Biolytika, Lund, Sweden) using a binding buffer of $\mathrm{pH} 5.0$ and an elution buffer of $\mathrm{pH} 1.6$ from Biolytika. The chromatographic system consisted of two M 510 pumps, an M 484 detector, an M 740 data module (all from Waters, Milford, MA, USA), a 1-ml sample loop and a Rheodyne injection valve. The chromatographic conditions were as follows: after injection, sample loading for $2 \mathrm{~min}$ and washing with binding buffer at a flow-rate of $2 \mathrm{ml} / \mathrm{min}$, followed by desorption with elution buffer at a flow-rate of $3 \mathrm{ml} / \mathrm{min}$ for $2 \mathrm{~min}$. Equilibration with binding buffer for at least $3 \mathrm{~min}$ at $2 \mathrm{ml} / \mathrm{min}$ was necessary before 
injection of the next sample. The concentration of $\mathrm{mAb}$ was calculated from the peak area at 280 $\mathrm{nm}$ previously calibrated with a standard solution.

Sodium dodecyl sulphate-polyacrylamide gel electrophoresis (SDS-PAGE) and isoelectric focussing (IEF). SDS-PAGE was carried out using the Mini-Protean gel system and high-molecular-mass protein standards (for $7.5 \%$ gels under non-reducing conditions) or low-molecular-mass protein standards (for $12 \%$ gels under reducing conditions) from Bio-Rad. The buffer system introduced by Laemmli [7] was used. Alternatively, SDS-PAGE and IEF were carried out using the Pharmacia Phast system employing Phast gels following the manufacturer's instructions.

High-performance size-exclusion chromatography (HPSEC). For HPSEC, an HPLC system equipped with a WISP M 712 autosampler, an M 510 pump and an $M 481$ variable-wavelength detector (all from Waters) was used. The chromatography was carried out on a Protein Pak 300 sw column (Waters) using $0.05 M$ Tris-0.05 $M$ $\mathrm{Na}_{2} \mathrm{SO}_{4}$ ( $\mathrm{pH}$ 7.2) as the mobile phase. The sample size was $100 \mu \mathrm{l}$, the flow-rate was 0.5 $\mathrm{ml} / \mathrm{min}$ and the detector was adjusted to $280 \mathrm{~nm}$.

Cytofluorimetry. Flow cytometric analysis was performed by standard techniques. Briefly, 2 . $10^{5}$ cells of a CD4 ${ }^{+}$cell line (CB-15 [8]) were incubated first with human $\operatorname{IgG}(10 \mathrm{mg} / \mathrm{ml})$ and washed twice. Appropriate dilutions of $\mathrm{mAb}$ MAX.16H5 were added, incubated on ice for 30 min and washed twice. Bound antibody was detected by fluorescein isothiocyanate-conjugated anti-mouse $\mathrm{F}(\mathrm{ab})_{2}$ fragments (DAKO, Hamburg, Germany). Cells were analysed on an EPICS profile cell sorter (Coulter, Hialeah, FL, USA). MAX.16H5 preparations were compared with standards in dilution experiments using the percentage of stained cells and the mean fluorescence intensity as parameters.

Tests for pyrogenicity. The objective of the tests is the determination of the safety of the product with respect to the presence of pyrogenic material. The rabbit pyrogen test measures rises in body temperature of the rabbit induced by intravenous (i.v.) injection of the product to be examined. Rabbits were injected with $\mathrm{mAb}$
MAX.16H5 at $0.3 \mathrm{mg} / \mathrm{kg}$ body mass. The test was carried out according to the guidelines in the European Pharmacopoeia. Alternatively, the Pyroquant 1 test kit, an in vitro Limulus amoebocyte lysate assay, was used according to the manufacturer's instructions (Pyroquant Diagnostik, Walldorf, Germany). This test was usually employed to measure the pyrogen content of column eluates after CIP.

Sterility test. The solution to be tested for sterility was incubated at $37^{\circ} \mathrm{C}$ for at least $5-6$ days and then checked by light microscopy for sterility.

Abnormal toxicity. In this test the safety of the product with respect to its parenteral or enteral toxicity was assessed. The test was carried out according to the European Pharmacopoeia.

Mouse DNA content. mAb solutions were concentrated by lyophilization and a maximum of $5 \mathrm{ml}$ were digested in $10 \mathrm{mM}$ Tris- $\mathrm{HCl}(\mathrm{pH}$ 8.0)-10 $\mathrm{m} M$ EDTA-1\% SDS with proteinase $\mathrm{K}$ $(500 \mu \mathrm{g})$ overnight. Samples were extracted with phenol-chloroform-isoamyl alcohol and then with chloroform and the aqueous phase was precipitated with $10 \mathrm{pg}$ of tRNA and 2.5 volumes of ethanol at $-20^{\circ} \mathrm{C}$. The precipitate was centrifuged at $15000 \mathrm{~g}\left(4^{\circ} \mathrm{C}, 20 \mathrm{~min}\right)$ and washed once with $70 \%$ ethanol. The pellet was dissolved in $200 \mu \mathrm{l}$ of $0.5 \mathrm{M} \mathrm{NaOH}$ and denatured at $95^{\circ} \mathrm{C}$ for $10 \mathrm{~min}$. After cooling, the samples were transferred to a Hybond $\mathrm{N}^{+}$membrane (Amersham, Braunschweig, Germany) with the Manifold slot apparatus (Schleicher \& Schüll, Dassel, Germany), and washed twice with $200 \mu 1$ of SSC buffer $[0.3 M \mathrm{NaCl}-0.03 M$ sodium citrate $(\mathrm{pH}$ 7.0)]. DNA from Balb/c mice, that was sheared by short ultrasonic treatment in an ultrasound water-bath, was used as a standard. The concentration was determined by measuring the absorbance at $260 \mathrm{~nm}$. Standard DNA and sample DNA were treated in an identical way as follows. DNA (1 ng and 500,100, 50, 20, 10, 5, 2 and 0 pg) was applied in parallel on the filter. Bound DNA was detected with $20 \mathrm{ng}$ of radiolabelled Balb/c mouse DNA prepared with $30-\mu \mathrm{Ci}$ $\left[{ }^{32} \mathrm{P}\right] \mathrm{dATP}$ by the polypriming method of Feinberg and Vogelstein [9]. Hybridization and washing were performed according to the protocol of 
Church and Gilbert [10] with $5 \cdot 10^{6}-1 \cdot 10^{6} \mathrm{cpm} /$ $\mathrm{ml}$ at $65^{\circ} \mathrm{C}$ overnight. Exposure for $3 \mathrm{~h}$ or overnight with an intensifying screen allowed the detection of 2-5 pg of DNA.

$n$-Hexane content. $n$-Hexane was determined using headspacc GC. The GC apparatus (PcrkinElmer F42) was equipped with a 2-m column packed with $5 \%$ Benton 34 and 5\% DDP on Chromosorb W NAW (80-100 mesh). The samples (2-ml volume) containing $1 \mathrm{mg} / \mathrm{ml}$ of $\mathrm{mAb}$ MAX. $16 \mathrm{H} 5$ were heated at $80^{\circ} \mathrm{C}$ for $2 \mathrm{~h}$. Nitrogen was used as the carrier gas. The column oven was held at $100^{\circ} \mathrm{C}$ isothermally. Flame ionization detection (FID) was used. Calibration was done by running samples with and without addition of standard.

Pristane content. Pristane was extracted from an aqueous solution containing mAb MAX.16H5 ( $1 \mathrm{ml} ; \mathrm{mAb}$ concentration $1 \mathrm{mg} / \mathrm{ml}$ ) by addition of $0.5 \mathrm{~g}$ of $\mathrm{NaCl}$ and $1 \mathrm{ml}$ of $n$-hexane and shaking for $30 \mathrm{~min}$. The $n$-hexane extract was analysed for pristane on a DB1 fused-silica capillary ( $30 \mathrm{~m} \times 0.32 \mathrm{~mm}$ I.D.). Nitrogen was used as the carrier gas. The temperature was programmed from 150 to $290^{\circ} \mathrm{C}$ at $5^{\circ} \mathrm{C} / \mathrm{min}$. FID was used. Calibration was done by running samples with and without addition of standard.

Viral content. Contamination with viruses was controlled by the mouse antibody production test. Briefly, 21-day-old anti-viral antibody-free Han:NMRI mice were injected with purified MAX.16H5 in solution. After 30 days, sera from injected mice were collected and tested for antibodies against the following viruses: hantaanvirus, lymphocytic choriomeningitis virus, reovirus type 3 , sendaivirus, polyomavirus, ectromeliavirus, mouse rotavirus, $\mathrm{K}$ virus, mink virus of mice, mouse adenovirus, Theiler's encephalomyelitis virus, mouse hepatitis virus, pneumonia virus of mice, mouse cytomegalivirus, mouse thymic virus and mycoplasma pulmonis. Lactate dehydrogenase virus was tested in sera 4 days after infection.

\section{RESULTS AND DISCUSSION}

Preparation of mAbs for human therapy has to take into account the following requirements: (i) $\mathrm{mAb}$ must be separated from contaminating proteins present in ascites fluid or cell culture supernatant; (ii) other contaminating compounds such as mouse DNA, viruses, pyrogens and irritants have to be removed; and (iii) $\mathrm{mAb}$ must be sterile and pyrogen-free. As the final product is expected to contain a very high degree of active antibody, the biological activity of the $\mathrm{mAb}$ must be preserved during all purification steps.

\section{Analytical-scale separations}

One of the easiest ways to purify IgG mAbs is affinity chromatography on protein $\mathrm{A}$ or protein $\mathrm{G}$ matrices [1]. Although problems with $\mathrm{mAb}$ for human therapy sometimes occur when traces of protein $A / G$ are co-eluted with $\mathrm{mAb}$, these can be overcome by a second column chromatographic step, namely gel filtration to separate $\mathrm{mAb}$ and protein $\mathrm{A} / \mathrm{G}$. However, it is known that murine $\mathrm{mAb}$ of $\mathrm{IgG}$ subtype 1 bind to protein $\mathrm{A} / \mathrm{G}$ with a lower affinity than other IgG subclasses [1]. Indeed, preliminary experiments revealed that mAb MAX.16H5 (IgG subclass 1) did not bind to protein $A$ or protein $G$ at all. Therefore, a schedule using other separation principles had to be developed.

Using anion-exchange chromatography on MonoQ 5/5 (Pharmacia), we observed binding of mAb MAX.16H5 with $40 \mathrm{~m} M$ NaCl-20 mM Tris- $\mathrm{HCl}(\mathrm{pH} \mathrm{7.5)}$ and elution on increasing the $\mathrm{NaCl}$ concentration linearly to $150 \mathrm{mM}$. Raising the $\mathrm{NaCl}$ concentration subsequently to $1 M$ led to the elution of further material absorbing at $280 \mathrm{~nm}$. Spiking experiments showed that DNA was also bound strongly to the column and eluted at $0.8-1.0 \mathrm{M} \mathrm{NaCl}$ (see also below). Several column runs using ascites fluid or purified MAX.16H5 were carried out to optimize the gradient. We ended up with the following gradient at a flow-rate of $0.5 \mathrm{ml} / \mathrm{min}$ : loading and washing at $40 \mathrm{mM} \mathrm{NaCl}$, following by a linear gradient to $150 \mathrm{mM} \mathrm{NaCl}$ within $20 \mathrm{~min}$, followed by isocratic elution for $10 \mathrm{~min}$ at 150 $\mathrm{m} M \mathrm{NaCl}$, followed by a linear gradient to $1 M$ $\mathrm{NaCl}$ in $10 \mathrm{~min}$ and then $10 \mathrm{~min}$ of isocratic elution at $1 M \mathrm{NaCl}$ [eluents were buffered to $\mathrm{pH} 7.5$ with $20 \mathrm{mM}$ Tris- $\mathrm{HCl}$ (Fig. 1)]. This procedure resulted in a product that, on the protein level, was already more than $95 \%$ pure 


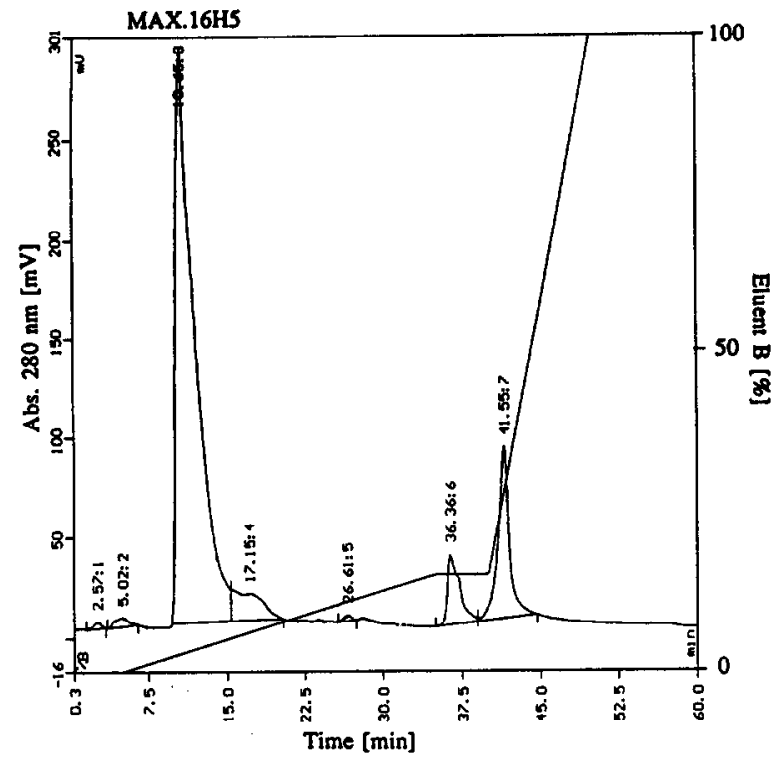

Fig. 1. Analytical-scale purification of $\left(\mathrm{NH}_{4}\right)_{2} \mathrm{SO}_{4}$-precipitated material from ascites fluid. A $1.75-\mathrm{mg}$ amount of protein was analysed on MonoQ 5/5 using buffers A [ $40 \mathrm{mM}$ $\mathrm{NaCl}-20 \mathrm{~m} M$ Tris- $\mathrm{HCl}(\mathrm{pH} \mathrm{7.5)}]$ and B $[1 M$ NaCl-20 $\mathrm{m} M$ Tris- $\mathrm{HCl}(\mathrm{pH} \mathrm{7.5)]} \mathrm{and} \mathrm{the} \mathrm{following} \mathrm{gradient} \mathrm{at} \mathrm{a} \mathrm{flow-rate}$ of $0.5 \mathrm{ml} / \mathrm{min}: 0 \mathrm{~min}, 0 \% ; 5 \mathrm{~min}, 0 \% ; 25 \mathrm{~min}, 15 \% ; 30 \mathrm{~min}$, $15 \% ; 40 \mathrm{~min}, 100 \% ; 50 \mathrm{~min}, 100 \% \mathrm{~B}$. The pressure was $\mathrm{ca}$. 30 bar. The elution position of mAb MAX.16H5 is indicated.

(Table 1). However, a second run on MonoQ and especially on Q-Sepharose preparative columns, had to be carried out to obtain a higher removal rate of contaminating DNA (see below).

As the second step, hydrophobic interaction chromatography (HIC) was introduced (i) to purify the protein further, (ii) to remove DNA (see below) and (iii) to remove pyrogens. For analytical-scale chromatography two different matrices were used: alkyl-Sepharose and phenylSepharose (both from Pharmacia). The mAb MAX.16H5 bound to both columns at high salt concentrations. For the alkyl-Sepharose matrix $1.5 M\left(\mathrm{NH}_{4}\right)_{2} \mathrm{SO}_{4}-70 \mathrm{mM} \mathrm{K}_{2} \mathrm{HPO}_{4}-\mathrm{KH}_{2} \mathrm{PO}_{4}$ (pH 7.2) was needed, whereas with the more hydrophobic phenyl-Sepharose only $0.5 \mathrm{M}$ $\left(\mathrm{NH}_{4}\right)_{2} \mathrm{SO}_{4}-70 \mathrm{mM} \quad \mathrm{K}_{2} \mathrm{HPO}_{4}-\mathrm{KH}_{2} \mathrm{PO}_{4} \quad(\mathrm{pH}$ 7.2) was necessary. From both columns $\mathrm{mAb}$ MAX.16H5 could be eluted by decreasing the $\left(\mathrm{NH}_{4}\right)_{2} \mathrm{SO}_{4}$ concentration to zero. We finally chose phenyl-Sepharose as it turned out that no preparative alkyl-Sepharose columns were commercially available. As can be seen in Table $\mathbf{I}$, no further protein purification on the analytical scale could be achieved. However, spiking experiments revealed a significant removal of DNA (see below).

Gel filtration was chosen as the final procedure using a Superdex 200 Prep grade column. Within a single step, (i) further protein purification, especially removal of potentially existing $\mathrm{mAb}$ dimers or polymers, (ii) an estimation of the molecular mass and (iii) an exchange of the buffer to phosphate-buffered physiological $\mathrm{NaCl}$ solution could be achieved. Material prepurified on MonoQ and phenyl-Sepharose on the analytical scale eluted as a single peak on Superdex 200 (Fig. 2, Table I).

\section{DNA removal}

Spiking experiments with calf thymus DNA were carried out on an analytical scale with optimized elution protocols for each chromato-

\section{TABLE I}

\section{PURIFICATION OF mAb MAX.16H5 ON AN ANALYTICAL SCALE}

Ammonium sulphate-precipitated material from ascites fluid containing $5 \mathrm{mg}$ of protein was purified during subsequent runs on Mono Q 5/5 (two runs), phenyl-Sepharose and Superdex 200 Prep grade. For separation conditions, see Experimental.

\begin{tabular}{lllc}
\hline Column type/method & Protein (mg) & mAb (mg) & Yield (\%) \\
\hline $\left.\mathrm{NH}_{4}\right)_{2} \mathrm{SO}_{4}$ precipitate & 5.0 & 3.7 & 100 \\
MonoQ 5/5 (1st run) & 4.5 & 3.3 & 89 \\
MonoQ 5/5 (2nd run) & 3.0 & 3.0 & 81 \\
Phenyl-Sepharose & 2.7 & 2.7 & 73 \\
Superdex 200 Prep grade & 2.4 & 2.4 & 65 \\
\hline
\end{tabular}




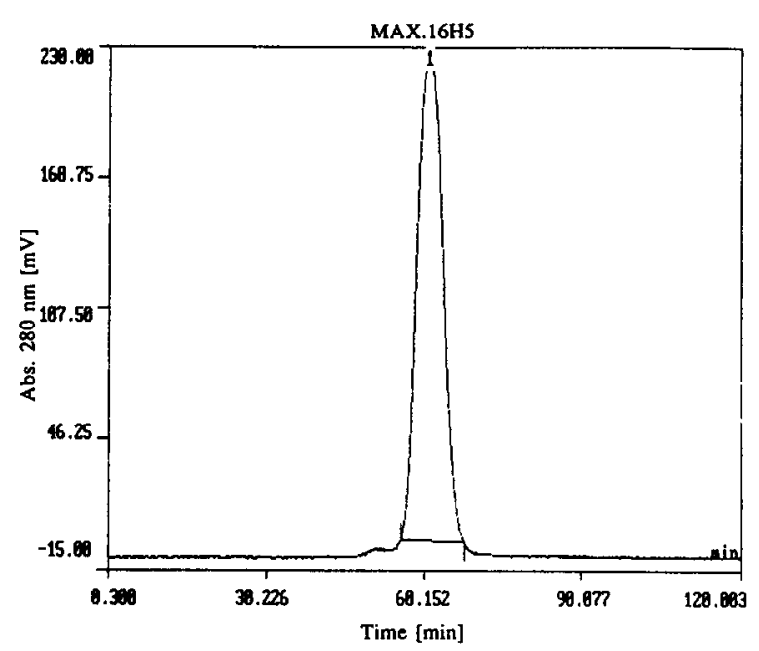

Fig. 2. Analytical-scale separation of mAb MAX.16H5 on Superdex 200 Prep grade. A 12.4-mg amount of mAb MAX.16H5 previously purified on MonoQ (two runs) and phenyl-Sepharose was chromatographed on HiLoad Superdex 200 Prep grade 16/60 using $75 \mathrm{~m} M$ NaCl-60 $\mathrm{m} M$ $\mathrm{Na}_{2} \mathrm{HPO}_{4}-\mathrm{NaH}_{2} \mathrm{PO}_{4}$ (pH 7.4) as elution buffer at a flowrate $0.5 \mathrm{ml} / \mathrm{min}$. The elution position of MAX.16H5 is indicated. In this particular preparation some high-molecular-mass contaminations were observed.

graphic step. As shown in Table II, the most significant removal was achieved by anion-exchange chromatography on Q-Sepharose. Phenyl-Sepharose was less effective, whereas gel filtration did not remove DNA significantly. As a factor of $>10^{12}$ has to be achieved for the whole purification procedure [2], a second run on QSepharose was considered necessary.

\section{Preparative-scale purification}

Separation protocols optimized under analytical conditions were linearly scaled up using BioPilot columns with increased column diameter but identical or similar length. However, in some instances modifications were introduced to increase the separation efficiency.

Before chromatography, mAb MAX.16H5 was enriched from ascites fluid by $\left(\mathrm{NH}_{4}\right)_{2} \mathrm{SO}_{4}$ precipitation (Table III). Subsequently, a lipid extraction with $n$-hexane was carried out. This procedure appeared to be necessary as experiments on the analytical scale indicated that the lipid content in ascites fluid interfered with the column performance and reduced column lifetime. It is important to mention that the extraction with $n$-hexane did not reduce the biological activity of mAb MAX.16H5. Problems occurred, however, in removing traces of $n$-hexane and precipitated proteins of unknown nature from the aqueous solution. Therefore, an ultracentrifugation step had to be introduced. With this step the remaining traces of $n$-hexane could be removed satisfactorily. However, some precipitated protein remained in the solution, leading to significant sample loss during sterile filtration through $0.2-\mu \mathrm{m}$ filters (Table III).

The material was chromatographed twice on Q-Sepharose HP 35/100 (Figs. 3 and 4). In the first step, a significant separation from material eluting closely after mAb MAX.16H5 and at higher salt concentrations was achieved (Fig. 3

\section{TABLE II}

\section{REMOVAL OF ADDED DNA BY COLUMN CHROMATOGRAPHIC STEPS}

Mixtures of mAb MAX.16H5 (0.5-1 mg) and $1 \mathrm{mg}$ of calf thymus DNA were chromatographed on HiLoad Q-Sepharose HP 26/10, HiLoad phenyl-Sepharose HP 16/10 and HiLoad Superdex 200 16/60 Prep grade using identical buffer systems as indicated for the preparative runs under Experimental. The elution protocols were adapted to the column sizes. DNA content was measured in the MAX.16H5 fraction by fluorimetry using bisbenzimide $\mathrm{H} 33258$.

\begin{tabular}{lllll}
\hline Chromatography & Column matrix & $\begin{array}{l}\text { DNA } \\
\text { added }\end{array}$ & $\begin{array}{c}\text { DNA } \\
\text { found }\end{array}$ & Factor $^{a}$ \\
\hline Anion-exchange & Q-Sepharose HP & $1 \mathrm{mg}$ & $<10 \mathrm{ng}$ & $>10^{5}$ \\
Hydrophobic interaction & Phenyl-Sepharose HP & $1 \mathrm{mg}$ & $592 \mathrm{ng}$ & $1.7 \cdot 10^{3}$ \\
Gel filtration & Superdex 200 & $1 \mathrm{mg}$ & $507 \mu \mathrm{g}$ & 1.97 \\
\hline
\end{tabular}

${ }^{a}$ Reduction factor calculated as [DNA added]/[DNA found]. 
TABLE III

\section{PREPARATIVE-SCALE PURIFICATION OF mAb MAX.16H5}

A batch of ascites fluid containing $16 \mathrm{~g}$ of total protein and about $7 \mathrm{~g}$ of mAb was purified by ammonium sulphate precipitation and the four column chromatographic steps as outlined in Table I and Experimental. Note the sample loss in the sterile filtration step caused by clogging of macromolecules in the filter. The yield was calculated as the percentage of mAb compared with that in ascites fluid. The purity was calculated as the percentage of mAb (as measured by ELISA) compared with total protein (as measured by protein determination) in each step of the procedure.

\begin{tabular}{lclcc}
\hline Step & Protein $(\mathrm{g})$ & $\mathrm{mAb}(\mathrm{g})$ & Yield $(\%)$ & Purity $(\%)$ \\
\hline Ascites fluid & 16.00 & 6.94 & 100 & 43 \\
$\left(\mathrm{NH}_{4}\right)_{2} \mathrm{SO}_{4}$ precipitate & 10.08 & 6.29 & 91 & 62 \\
Filtration $(0.22 \mu \mathrm{m})$ & 5.5 & n.d. $^{a}$ & - & - \\
Q-Sepharose HP II & 4.05 & 3.59 & 52 & 89 \\
Phenyl-Sepharose & 2.80 & 2.43 & 35 & 87 \\
Superdex 200 pg & 2.09 & 2.10 & 30 & 100 \\
\hline
\end{tabular}

${ }^{a}$ Not determined.

and Fig. 7, lanes 1 and 2). The second run did not result in enhanced protein purification (Fig. 4). This step was carried out to obtain more complete removal of DNA as discussed above.

The subsequent HIC on phenyl-Sepharose HP

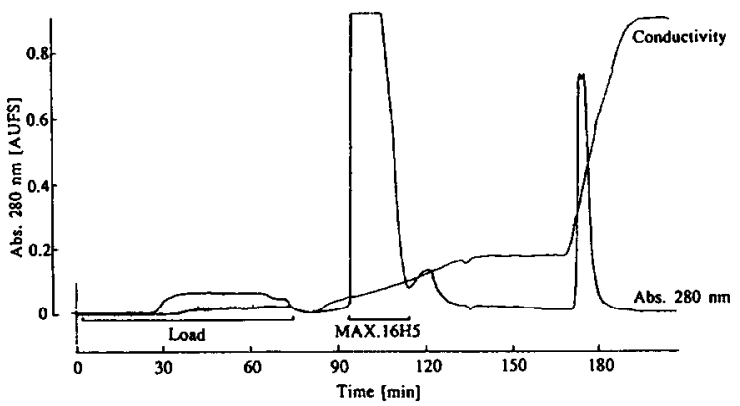

Fig. 3. Preparative-scale purification of mAb MAX.16H5 on BioPilot Q-Sepharose HP 35/100. About $800 \mathrm{mg}$ of protein containing mAb MAX.16H5 previously purified by $\left(\mathrm{NH}_{4}\right)_{2} \mathrm{SO}_{4}$ precipitation were chromatographed on BioPilot Q-Sepharose HP $35 / 100$ using a BioPilot system. The chromatographic system including column was made pyrogen-free by CIP as detailed under Experimental. The column was equilibrated with buffer $A$ [ $40 \mathrm{mM} \mathrm{NaCl}-20 \mathrm{mM}$ Tris-HCl $(\mathrm{pH} 7.5)]$ and sample was loaded at a flow-rate of 3.0 $\mathrm{ml} / \mathrm{min}$. Elution was done by pumping increasing percentages of buffer $\mathrm{B}[1 M \mathrm{NaCl}-20 \mathrm{~m} M$ Tris- $\mathrm{HCl}(\mathrm{pH} \mathrm{7.5)}]$ at a flow rate of $3.6 \mathrm{ml} / \mathrm{min}$. The gradient (detailed under Experimental) is graphically displayed as the conductivity trace of the column eluate in the chromatogram. The elution position of MAX.16H5 is indicated.
$35 / 100$ resulted in a single peak (Fig. 5). In contrast to analytical-scale chromatography, slight tailing of mAb MAX.16H5 was observed. Although no further protein purification was achieved (Table III, Fig. 7), this chromatographic step contributed to removal of DNA (Table II) and probably of pyrogens.

For gel filtration chromatography the material eluted from phenyl-Sepharose had to be concentrated by ultrafiltration.

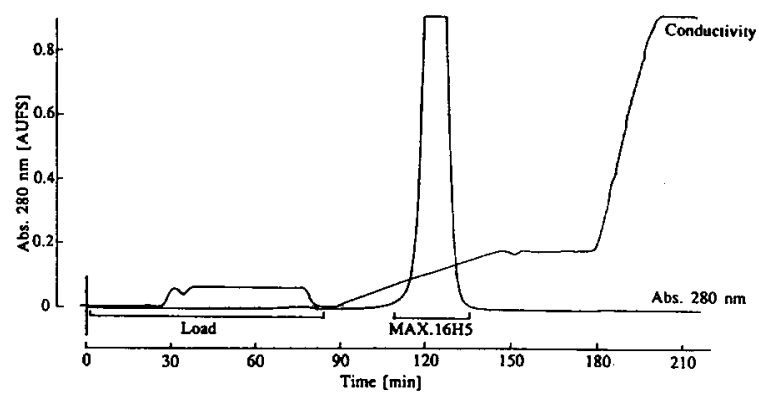

Fig. 4. Preparative-scale purification of mAb MAX.16H5 on BioPilot Q-Sepharose HP 35/100, second run. MAX.16H5 was chromatographed under identical conditions to those in Fig. 3 a second time on Q-Sepharose. The sample was obtained from a first preparative run on BioPilot Q-Sepharose dissolved in elution buffer containing about $100 \mathrm{mM}$ $\mathrm{NaCl}$. In order to facilitate binding to the column, MAX.16H5 was diluted three fold with sterile, pyrogen-free water before loading. The elution position of MAX.16H5 is indicated. 


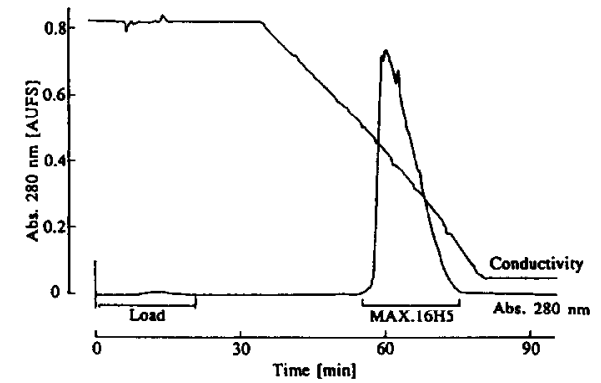

Fig. 5. Preparative-scale purification of mAb MAX.16H5 on BioPilot phenyl-Sepharose HP 35/100. About $700 \mathrm{mg}$ of $\mathrm{mAb}$ MAX.16H5 previously purified on Q-Sepharose (two runs) were loaded on BioPilot phenyl-Sepharose HP 35/100 using buffer A $\left[\begin{array}{lllll}0.5 & M & \left(\mathrm{NH}_{4}\right)_{2} \mathrm{SO}_{4}-70 & \mathrm{mM} & \mathrm{K}_{2} \mathrm{HPO}_{4}-\end{array}\right.$ $\mathrm{KH}_{2} \mathrm{PO}_{4}(\mathrm{pH} \mathrm{7.2)]} \mathrm{at} \mathrm{a} \mathrm{flow-rate} \mathrm{of} 10 \mathrm{ml} / \mathrm{min}$. Elution was carried out by pumping increasing percentages of buffer $\mathrm{B}$ [70 $\left.\mathrm{mM} \mathrm{K} \mathrm{K}_{2} \mathrm{HPO}_{4}-\mathrm{KH}_{2} \mathrm{PO}_{4}(\mathrm{pH} 7.2)\right]$ at $10 \mathrm{ml} / \mathrm{min}$. The gradient (detailed under Experimental) is graphically displayed as the conductivity trace of the column eluate in the chromatogram. The elution position of MAX.16H5 is indicated.

Gel filtration was performed on Superdex 200 Prep grade $35 / 600$ or $60 / 600$. The chromatograms usually revealed separation of $\mathrm{mAb}$ MAX.16H5 from contaminating proteins of $M_{\mathrm{r}}$ 65 000-70000 and low-molecular-mass material (Fig. 6). In addition to purification nearly up to $100 \%$, an exchange of the buffer to phosphate-

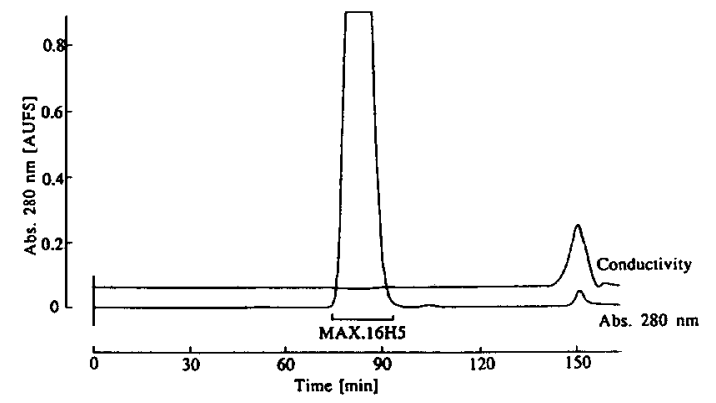

Fig. 6. Preparative-scale purification of $\mathrm{mAb}$ MAX.16H5 on BioPilot Superdex 200 Prep grade 60/600. About $900 \mathrm{mg}$ of mAb MAX.16H5 previously purified on Q-Sepharose (two runs) and phenyl-Sepharose were chromatographed on BioPilot Superdex 200 Prep grade 60/600 using $75 \mathrm{mM}$ NaCl-60 mM Na $\mathrm{NaPO}_{4}-\mathrm{NaH}_{2} \mathrm{PO}_{4}(\mathrm{pH}$ 7.4) as elution buffer at a flow-rate of $11.7 \mathrm{ml} / \mathrm{min}$. The elution position of MAX.16H5 is indicated. This preparation contained some contaminating material eluting at $103 \mathrm{~min}\left(M_{\mathrm{r}} c a .70000\right)$ and $150 \mathrm{~min}$ (low-molecular-mass material). buffered physiological $\mathrm{NaCl}$ solution was achieved by this step (Table III, Fig. 7).

\section{Analytical characterization of the bulk final processed product (BFPP)}

In the bulk final processed product, identity, purity and possible contaminations were studied. The identity was confirmed by IgG-specific ELISA and an HPLC method specifically designed to determine $\mathrm{mAb}$, namely Pro Ana Mabs (Table IV). Both methods gave nearly identical results for IgG concentration. The identity as an anti-CD4 antibody and the biological activity were assessed by cytofluorimetric analysis (Table IV).

The purity was determined electrophoretically and chromatographically. A single band at about $M_{\mathrm{r}} 160000$ appeared in SDS-PAGE under nonreducing conditions (Fig. 7 , lanc 4 , and Table

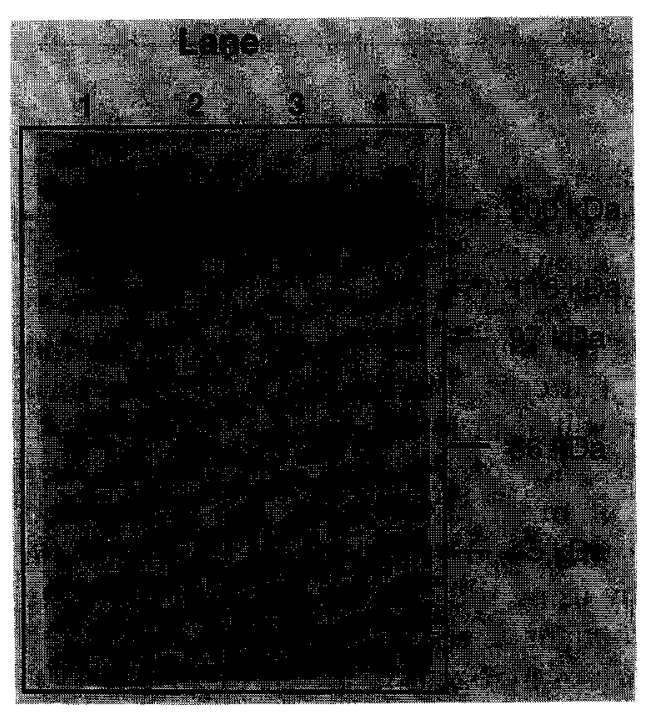

Fig. 7. SDS-PAGE of mAb MAX.16H5 at different stages of the purification schedule SDS-PAGE was carried out using a 7.5\% gel, the Laemmli buffer system [7] and the MiniProtean electrophoresis system from Bio-Rad. Lanes: $1=$ MAX.16H5 after $\left(\mathrm{NH}_{4}\right)_{2} \mathrm{SO}_{4}$ precipitation; $2=\mathrm{MAX}$.16H5 after two runs on Q-Sepharose; $3=\mathrm{MAX} .16 \mathrm{H} 5$ after a further run on phenyl-Sepharose; $4=$ MAX.16H5 after a further run on Superdex 200 . An amount of $5 \mu \mathrm{g}$ of protein was loaded on to each lane. Staining was done with Coomassie brilliant blue. Electrophoretic mobilities of marker protcins are indicated. $\mathrm{kDa}=$ Kilodalton. 
TABLE IV

FINAL TESTING OF PURIFIED mAb MAX.16H5

Purified MAX.16H5 (BFPP) was checked for identity, purity and possible contamination using several methods as outlined under Experimental.

\begin{tabular}{lll}
\hline Feature & Method & Result \\
\hline Identity & IgG-specific ELISA & $0.925 \mathrm{mg} / \mathrm{ml}$ \\
& Pro Ana Mabs & $1.14 \mathrm{mg} / \mathrm{ml}$ \\
& FACS analysis of CD4 ${ }^{+}$cells & Cells stained \\
Purity & SDS-PAGE (non-reducing) & Single band \\
& SDS-PAGE (reducing) & Two bands \\
& IEF & Microheterogeneity pH $5.92-6.4$ \\
& HPSEC & Single peak \\
Contamination: & & \\
Pyrogenicity & (1) Rabbit pyrogen test & Negative \\
& (2) Pyroquant 1 test & $<0.03$ endotoxin units \\
Sterility & Culture at $37^{\circ} \mathrm{C}$ for $5-6$ days & Sterile \\
Abnormal toxicity & According to European Pharmacopoeia & Negative \\
Mouse DNA & Dot blot $/$ hybridization assay & $<8 \mathrm{pg}$ per 20 mg \\
$n$-Hexane & GC and GC-MS & $<0.5 \mathrm{mg} / \mathrm{l}^{\circ}$ \\
Pristane & GC & $<0.5 \mathrm{mg} / 1^{a}$ \\
Viruses & Mouse antibody production & Negative for 17 \\
& test & viruses listed under Experimental \\
\hline
\end{tabular}

${ }^{a} 1 \mathrm{mg} / \mathrm{ml} \mathrm{mAb}$.

IV). Under reducing conditions two bands representing heavy and light chains were observed (data not shown). IEF revealed a microheterogeneity of mAb MAX.16H5 giving five bands within the $\mathrm{pH}$ range $5.92-6.40$, probably due to different patterns of glycosylation (Fig. 8). HPSEC resulted in a single peak (Table IV).

The presence of pyrogens was tested (i) by injection of mAb MAX.16H5 into rabbits and following their body temperature post-injection and (ii) by using the Limulus amoebocyte lysate test (Pyroquant 1 test). Both methods showed the absence of pyrogens in the BFPP (Table IV). The content of mouse DNA was determined by extraction of DNA from BFPP and by hybridization with radiolabelled specific DNA probes. In extracts corresponding to one therapeutic dose of MAX.16H5 (20 mg), DNA was not detected (Table IV). The absence of seventeen viruses in BFPP was assessed by the mouse antibody production test (Table IV). Pristane, which is injected into mice during the production period of ascites fluid and therefore could contaminate the
$\mathrm{mAb}$ preparation, was not present in the BFPP as tested by GC (Table IV). Also, $n$-hexane, which was used for extraction of lipids during the preparative process, was not found in the BFPP by GC and GC-MS (Table IV).

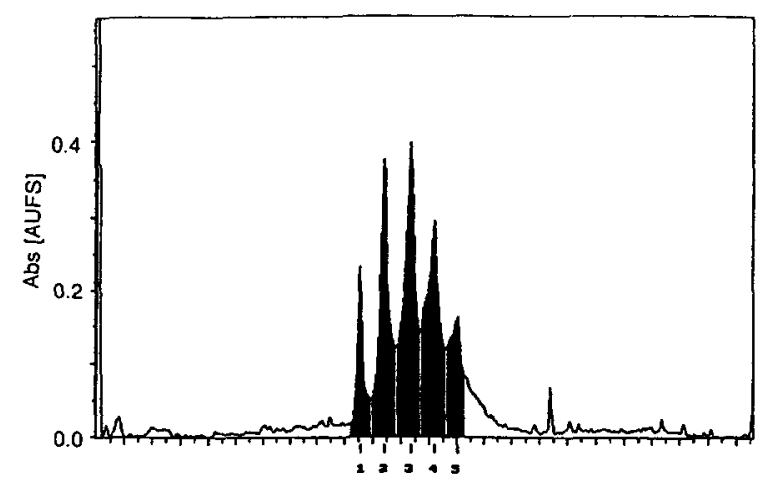

Fig. 8. Isoelectric focusing of purified mAb MAX.16H5. IEF was carried out using the Pharmacia PhastSystem employing a PhastGel with a gradient from pH 5.1 to 7. Densitometric analysis of the gel showed five major bands with isoelectric points at pH (1) 6.40 , (2) 6.25 , (3) 6.12 , (4) 6.02 and (5) 5.92 . 
Finally, the sterility of the solution was checked by incubation at $37^{\circ} \mathrm{C}$ for several days and subsequent light microscopy of the solution (Table IV).

\section{CONCLUSIONS}

A method was established on an analytical scale and successfully scaled-up to the preparative scale that resulted in a highly purified product. As mAb MAX.16H5 preparations were free from contaminating compounds such as other proteins, mouse DNA, viruses, pyrogens and irritants, single case treatments of human patients suffering from autoimmune diseases could be carried out using these mAb preparations with encouraging results (reviewed in ref. 3).

\section{ACKNOWLEDGEMENTS}

The Max Planck Research Unit for Rheumatology/Immunology is funded by the German Ministry for Research and Technology (BMFT) by grant No. 01 VM 8702 . This project was also supported by BMFT grant No. $01 \mathrm{ZU} 8607$ (to H.S.-K. and F.E.). H.S.-K. is recipient of a postdoctoral fellowship from the Deutsche Forschungsgemeinschaft (Schu 786/1-1). We thank Drs. D. Rohm and N. Kothe (Biotest Pharma, Dreieich, Germany) for the biochemical and pharmacological characterization of the bulk final processed product. Thanks are also expressed to Professor Dr. Gräf (Erlangen, Germany) for conducting the rabbit pyrogen tests and to Pharmacia (Freiburg, Germany) for supplying several FPLC columns for test runs. Mouse antibody production tests were carried out in the Zentralinstitut für Versuchstierzucht (Hannover, Germany).

\section{REFERENCES}

1 E. Harlow and D. Lane, Antibodies. A Laboratory Manual. Cold Spring Harbor Lahoratory, Cold Spring Harbor, 1988.

2 TIBTECH, 8 (1988) G5.

3 F. Emmrich, H. Schulze-Koops and G. Burmester, in M.E. Davies and J.T. Dingle (Editors), Handbook of Immunpharmacology, Academic Press, London, in press.

4 M. Jonker, W. Slingerland, H. Niphuis, E. Golub, G.B. Thornton, L. Smit and J. Goudsmit, in W. Knapp, B. Dörken, W.R. Gilles, E.P. Rieber, R.E. Schmidt, H. Stein and A.E.G.Kr. von dem Borne (Editors), Leukocyte Typing IV, Oxford University Press, London, New York, Tokyo, 1989, p. 319.

5 A. Williams, personal communication.

6 C. Labarca and K. Paigen, Anal. Biochem., 102 (1980) 344.

7 U.K. Laemmli, Nature, 227 (1970) 680.

8 B. Biesinger, I. Müller-Fleckenstein, B. Simmer, G. Lang, S. Wittmann, E. Platzer, R.C. Desrosiers and B. Fleckenstein, Proc. Natl. Acad. Sci. U.S.A., 89 (1992) 3116.

9 A.P. Feinberg and B. Vugelstein, Anal. Biochem., 132 (1983) 6.

10 G.M. Church and W. Gilbert, Proc. Natl. Acad. Sci. U.S.A., 81 (1984) 1991. 